\title{
Stability-indicating HPLC Method for Determination of 7,8,9,10-tetrahydroazepino[2,1b]quinazolin-12(6H)-one, a Potential Anticancer Agent
}

\author{
MEGHA SHARMA, N. K. UPADHYAY AND N. MAHINDROO* \\ School of Pharmaceutical Sciences, Shoolini University, Post Box-9, Solan-173 212, India \\ Sharma, et al.: Stability-indicating Method for Determination of a Potential Anticancer Agent
}

\begin{abstract}
7,8,9,10-tetrahydroazepino[2,1b]quinazolin-12(6H)-one, a synthetic analog of vasicine, has been reported to be an anticancer, bronchodilator, antiinflammatory, antitussive, antiarthritic and antiasthamatic compound, which is under preclinical development for anticancer activity. The development of a validated reverse phase high performance liquid chromatography method is herein reported for the analysis and stability assessment. The analytical method was optimized using a C18 column and methanol:water (80:20 $\mathrm{v} / \mathrm{v}$ ) as mobile phase at flow rate of $0.9 \mathrm{ml} / \mathrm{min}$. The eluents were monitored at $254 \mathrm{~nm}$. Retention time of 7,8,9,10-tetrahydroazepino[2,1b]quinazolin-12(6H)-one was observed to be $3.9 \mathrm{~min}$. It degraded significantly under alkaline conditions whereas negligible degradation was observed under acidic, oxidative, thermal and photolytic stress conditions. The peak of major degradation product, resulting from alkaline degradation, was well resolved from the peak of 7,8,9,10-tetrahydroazepino[2,1b]quinazolin-12(6H)-one. This method has been found to be linear, accurate, precise, robust, sensitive, specific, suitable and stability indicating.
\end{abstract}

Key words: Quinazolines, cancer, HPLC, stability-indicating method

7,8,9,10-tetrahydroazepino[2,1b]quinazolin-12(6H)one (TAZQ) (fig. 1), a synthetic analog of vasicine, is currently under preclinical studies for anticancer activity. Vasicine is a major alkaloid obtained from the leaves of Adhatoda vasica Nees, a wellknown medicinal plant used in Ayurvedic and Unani medicine ${ }^{[1]}$. TAZQ has been extensively studied as bronchodilator ${ }^{[2-7]}$. It inhibited lung phosphodiesterase activity, lipooxygenase activity, histamine release and antigen-induced mast cell degranulation ${ }^{[8]}$. It showed synergistic antiasthamatic activity in combination with ambroxol in ovalbumin sensitized guinea pigs $^{[5]}$. It showed antitussive activity in citric acid cough model in guinea pigs ${ }^{[9]}$. It's in vivo metabolic studies were performed in rhesus monkeys and Charles Foster rats.

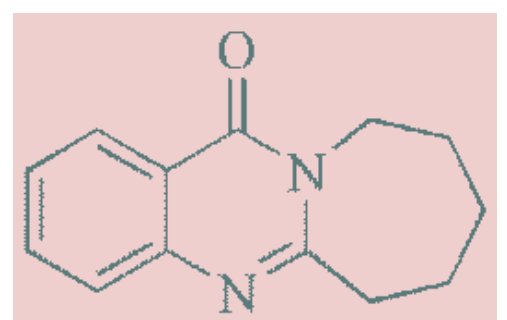

Fig. 1: TAZQ (7,8,9,10-tetrahydroazepino[2,1b]quinazolin12(6H)-one).

*Address for correspondence E-mail: Neeraj.Mahindroo@yahoo.com

November-December 2016
Various metabolites that were detected did not show any bronchodilatory activity ${ }^{[10,11]}$. TAZQ showed doserelated reduction in developing adjuvant arthritis in rats. It's $L_{50}$ was lower than $1000 \mathrm{mg} / \mathrm{kg}$ p.o, thus was safe at pharmacologically active doses ${ }^{[12]}$. Structure activity relationship of TAZQ as bronchodilator has been studied extensively ${ }^{[7]}$. It induced nuclear factor kappa-light-chain-enhancer of activated B cell (NF$\kappa \mathrm{B})$-mediated apoptosis in human colon carcinoma HCT-116 cell lines ${ }^{[13]}$. A recent study, showed that its antiproliferative activity is through inhibition of PI3k/ Akt/FoxO3a pathway ${ }^{[14]}$.

Although TAZQ has been studied extensively for its biological activities and is currently in pre-clinical studies as anticancer agent (with reference to personal communication with PK-PD Division, IIIM-CSIR, Jammu, India), its stability indicating assay method has

This is an open access article distributed under the terms of the Creative Commons Attribution-NonCommercial-ShareAlike 3.0 License, which allows others to remix, tweak, and build upon the work non-commercially, as long as the author is credited and the new creations are licensed under the identical terms

Accepted 18 November 2016

Revised 18 October 2016

Received 19 December 2015

Indian J Pharm Sci 2016;78(6):769-774 
not been reported yet. A validated stability indicating assay method must be employed to study the influence of storage on quality, safety and/or efficacy of a drug substance. Stress studies must be performed early in development phase to assess inherent stability of a drug. Validation of stability indicating assay method is essential to prove that it distinguishes active ingredients from degradation products and can measure their content without interference ${ }^{[15]}$. We report here the development of a validated reversed phase high performance liquid chromatography (RPHPLC) method for analysis of TAZQ and its successful application as a stability indicating assay.

\section{MATERIALS AND METHODS}

Water and methanol of HPLC grade, hydrochloric acid and sodium hydroxide were procured from Loba Chemi Pvt. Ltd., Mumbai, India. Hydrogen peroxide was from Finar, anthranilic acid was from SigmaAldrich, caprolactam was from Himedia and thionyl chloride was from Thomas Baker. All chemicals were of analytical grade and were used as received. The proton nuclear magnetic resonance ( $\left.{ }^{1} \mathrm{H}-\mathrm{NMR}\right)$ and liquid chromatography-mass spectrometry (LC-MS) were carried out at Sophisticated Analytical Instrumentation Facility, Panjab University, Chandigarh, India.

\section{Synthesis of TAZQ:}

TAZQ was synthesised according to a reported method $^{[2]}$. Anthranilic acid (5 g, $23 \mathrm{mmol}, 1$ equivalent) was dissolved in dry toluene. Thionyl chloride (14 $\mathrm{ml}$, in excess) was added to it and refluxed for three hours. The solvent was removed in vacuo to give corresponding sulphonamide anhydride. Caprolactam (4 g, $35 \mathrm{mmol}, 1.5$ equivalent), dissolved in toluene, was added to reaction mixture drop wise and stirred overnight at ambient temperature. The solvent was removed in vacuo, the residue was re-dissolved in chloroform and washed with $1 \mathrm{~N} \mathrm{HCl}$, organic layer was separated to remove any unreacted part. Aqueous layer was basified and extracted with chloroform. Organic layer was collected and solvent was removed in vacuo and residue was chromatographed over silica gel 60-120 mesh, with hexane-ethyl acetate gradient. TAZQ was obtained as pale yellow solid in $70 \%$ yield (mp 97-98 ${ }^{\circ}$, lit mp 98-99 $)^{[22]}$. Analytical purity was determined by RP-HPLC using Agilent Technologies 1200 HPLC system consisting of photo diode array (PDA) detector. Percent purity was found to be $98.6 \%$ and $97.4 \%$ using mobile phases methanol:water (80:20 $\mathrm{v} / \mathrm{v})$ and methanol:water $(78: 22 \mathrm{v} / \mathrm{v})$, respectively. TAZQ was spectrally characterized through IR (Agilent Cary 630 Fourier transform infrared spectrometer), ${ }^{1} \mathrm{H}-\mathrm{NMR}$ (Bruker Avance II 400 NMR spectrometer, $\mathrm{CDCl}_{3}$ ) and LC-MS (Waters, Q-TOF Micromass spectrometer). IR cm ${ }^{-1}: 3044,2925,1659,1588,1447$, 1395, 1235. ${ }^{1} \mathrm{H}-\mathrm{NMR}\left(\mathrm{CDCl}_{3}\right) \delta: 8.2500-8.2466(1 \mathrm{H}$, d, $J=8.04 \mathrm{~Hz}), 5.5366-5.2669$ ( $3 \mathrm{H}, \mathrm{m}), 4.4099-4.3856$ (2 H, m), 3.0908-3.0641 (2 H, m), 1.7-2.20 (6 H, m). LC-MS $m / z: 215.53(\mathrm{M}+1), 216.54(\mathrm{M}+2)$.

\section{HPLC instrumentation and conditions:}

The RP-HPLC method was developed on an Agilent Technologies 1200 HPLC system consisting of a binary pump, PDA detector, auto sampling injection system and C18 column (Agela technologies, Innoval, $4.6 \times 250 \mathrm{~mm}, 5 \mu)$. Data acquisition was done using EzChrome Elite software. Chromatographic parameters were optimized starting with methanol:water (50:50 $\mathrm{v} / \mathrm{v})$ as mobile phase. Flow rate, injection volume and run time were kept as $2 \mathrm{ml} / \mathrm{min}, 10 \mu \mathrm{l}$ and 30 min, respectively. Chromatographic conditions were optimized to obtain sharp and symmetric peak. The finalized chromatographic parameters are summed up in Table 1. Solvents were filtered through nylon membrane filters $(0.22 \mu$ pore size $)$ and sonicated for 15-20 min. Samples were filtered through syringe filter $(0.45 \mu$ pore size) prior to injection.

\section{Preparation of stock solution and calibration curve:}

Accurately weighed TAZQ was transferred to volumetric flask and volume was made up with methanol:water $(80: 20 \mathrm{v} / \mathrm{v})$ to obtain a $100 \mathrm{ppm}$ stock solution. Further dilutions of TAZQ $(6.25,12.5,25$, $50,100 \mathrm{ppm})$ were prepared and injected in triplicates to obtain the chromatograms. A calibration curve was constructed by plotting average peak area vs. concentration. Regression equation and correlation coefficient were computed.

\section{TABLE 1: OPTIMISED CHROMATOGRAPHIC} CONDITIONS FOR TAZQ

\begin{tabular}{lc}
\hline Parameter & Condition \\
\hline Stationary phase & Innoval C18 column $(4.6 \times 250 \mathrm{~mm}, 5 \mu)$ \\
Mobile phase & Methanol:water $(80: 20 \mathrm{v} / \mathrm{v})$ \\
Flow rate & $0.9 \mathrm{ml} / \mathrm{min}$ \\
Detector & Photo diode array \\
Injection volume & $5 \mu \mathrm{l}$ \\
Detection wavelength & $254 \mathrm{~nm}$ \\
Retention time & $3.9 \mathrm{~min}$ \\
\hline
\end{tabular}




\section{Validation and system suitability testing:}

The method was validated and tested for system suitability according to International Conference on Harmonization (ICH), United States Food and Drug Administration (USFDA) and United States Pharmacopoeia guidelines (USP). Linearity was determined by computing regression equation and correlation coefficient from calibration curve. For inter-day precision studies, analysis was carried out for three consecutive days at three concentration levels $(6.25,12.5$ and $25 \mathrm{ppm})$, each in triplicate. Analysis was carried out at three different times in a day at three concentration levels $(6.25,12.5$ and $25 \mathrm{ppm})$, each in triplicate, to study intraday precision. Percent relative standard deviations (RSD) of peak areas were calculated. Standard addition method was employed for accuracy studies. Spiking was done at levels of 80,100 and $120 \%$ in previously analysed sample of $25 \mathrm{ppm}$ to measure percent recovery by the assay of known added amounts of analyte. Robustness was measured by making small but deliberate changes in detection wavelength $( \pm 5 \mathrm{~nm})$, flow rate $( \pm 0.1 \mathrm{ml} /$ min) and organic content in mobile phase ( \pm 2 units). $\%$ RSD of peak areas was calculated. The specificity of the method was performed by determining resolution between the peak of analyte and closest eluting peak. Limit of detection (LOD) and limit of quantification (LOQ) were determined using the formulas, $\mathrm{LOD}=3.3 \times \sigma / \mathrm{S}$ and $\mathrm{LOD}=10 \times \sigma / \mathrm{S}$, where, ' $\sigma$ ' is the standard deviation of the response and ' $S$ ' is the slope of calibration curve. System suitability was evaluated by analysing six replicates of $12.5 \mathrm{ppm}$
TAZQ. Suitability for intended use was tested in terms of $\%$ RSD of retention time, $\%$ RSD of peak area, tailing factor and number of theoretical plates ${ }^{[16-20]}$.

\section{Forced degradation studies:}

The stability of TAZQ was studied under stress conditions. For hydrolytic degradation, different strengths of acid $(0.1 \mathrm{~N}, 1 \mathrm{~N}, 2 \mathrm{~N}, 5 \mathrm{~N} \mathrm{HCl})$, base $(0.1$ $\mathrm{N}, 1 \mathrm{~N} \mathrm{NaOH})$ and hydrogen peroxide $\left(\mathrm{H}_{2} \mathrm{O}_{2}\right)(3 \%$, $6 \%$ ) were employed. Accurately weighed $50 \mathrm{mg}$ of TAZQ was dissolved in $1 \mathrm{ml}$ of respective acid, base or $\mathrm{H}_{2} \mathrm{O}_{2}$ and kept for specified period of time at room temperature. For degradation with $0.1 \mathrm{~N} \mathrm{HCl}, 0.1 \mathrm{~N}$ $\mathrm{NaOH}$ and $3 \% \mathrm{H}_{2} \mathrm{O}_{2}$, solutions were refluxed at $80^{\circ}$ for $30 \mathrm{~min}$. The volume was made up to $50 \mathrm{ml}$ with methanol:water $(80: 20 \mathrm{v} / \mathrm{v})$ and $5 \mathrm{ml}$ of this solution was again diluted to get a final concentration of 20 $\mathrm{ppm}$. The stressed samples from acid or base hydrolysis were neutralized (with $\mathrm{NaOH}$ or $\mathrm{HCl}$ of appropriate strength) prior to injection. Thermal degradation was studied by exposing $10 \mathrm{mg}$ dry powder of TAZQ at $80^{\circ}$ in a temperature controlled oven for $4 \mathrm{~h}$. Photolytic degradation was studied by exposing $10 \mathrm{mg}$ dry powder of TAZQ to $365 \mathrm{~nm}$ UV light for $4 \mathrm{~h}$ in UV chamber. Using methanol:water (80:20 v/v) as solvent, $20 \mathrm{ppm}$ solutions of these stressed samples were prepared, filtered and injected. Analysis was performed by the developed method.

\section{RESULTS AND DISCUSSION}

TAZQ was synthesized and the spectral data of synthesized compound matched the literature reports.

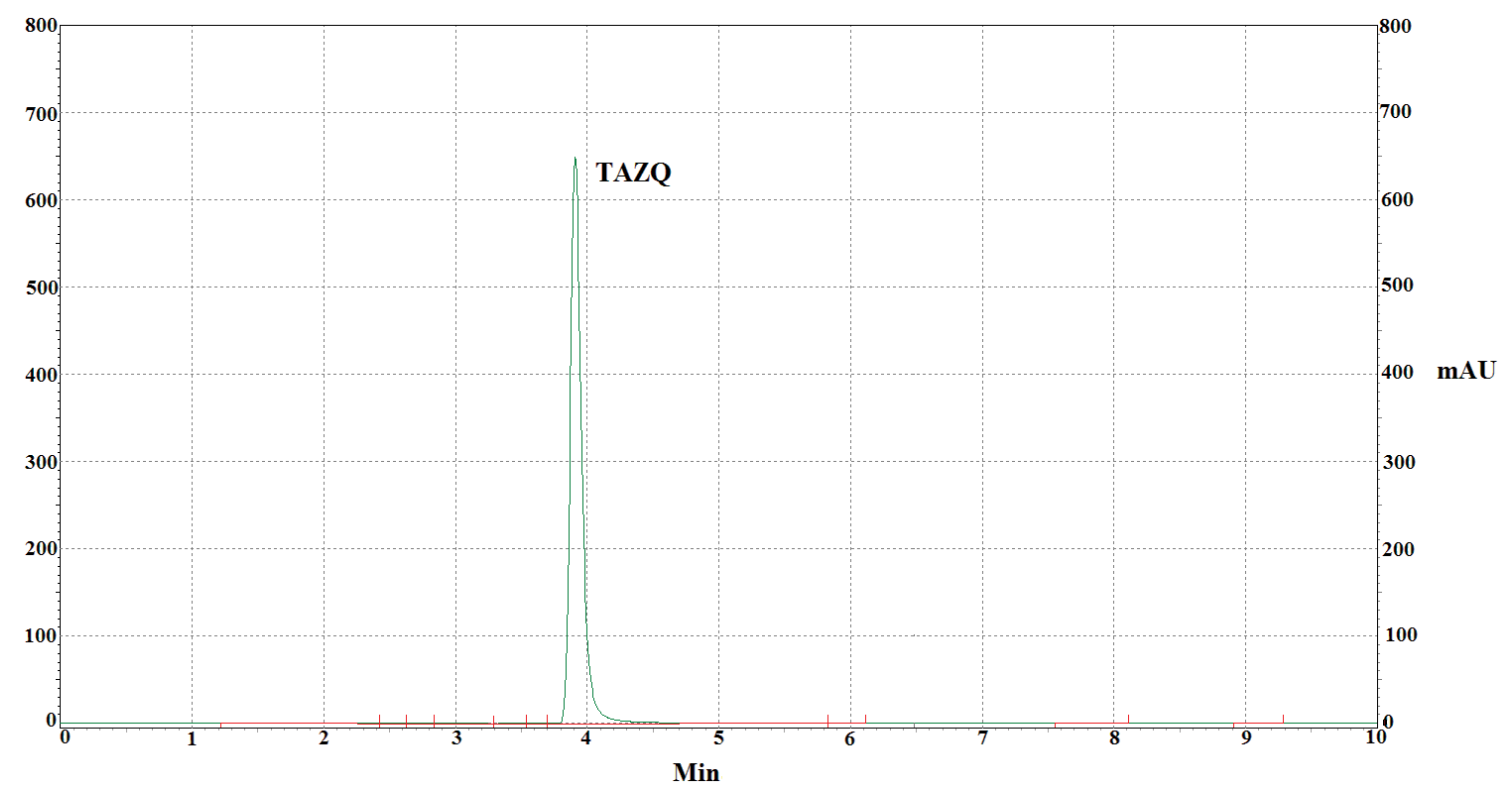

Fig. 2: HPLC chromatogram of TAZQ. 
Chromatographic conditions were optimized to obtain sharp and symmetric peak. The average retention time for TAZQ was $3.921 \pm 0.009 \mathrm{~min}$ (fig. 2). A calibration curve was plotted by taking $6.25,12.5,25,50$ and $100 \mathrm{ppm}$ of TAZQ (fig. 3 and Table 2). Results of validation and system suitability are summed up in Tables 3 and 4, respectively. All the observations complied with the acceptance criteria laid down by regulatory guidelines ${ }^{[19,21-23]}$. Forced degradation of TAZQ was performed under various stress conditions and stressed samples were analysed by standardized method. TAZQ did not show any degradation under acidic, oxidative, thermolytic and photolytic stress, as is evident by the chromatograms that show only a single peak of TAZQ at $3.9 \mathrm{~min}$ (fig. 4). Significant degradation (19.85\%) was observed in alkaline hydrolysis (fig. 5). Degradation level of $10-20 \%$ is considered acceptable for chromatographic assay validation $^{[24,25]}$. Chromatogram of alkaline degraded sample showed peaks of TAZQ, major degradant and minor degradant at retention times of $3.9,2.6$ and $5.5 \mathrm{~min}$, respectively. Resolution between the peaks

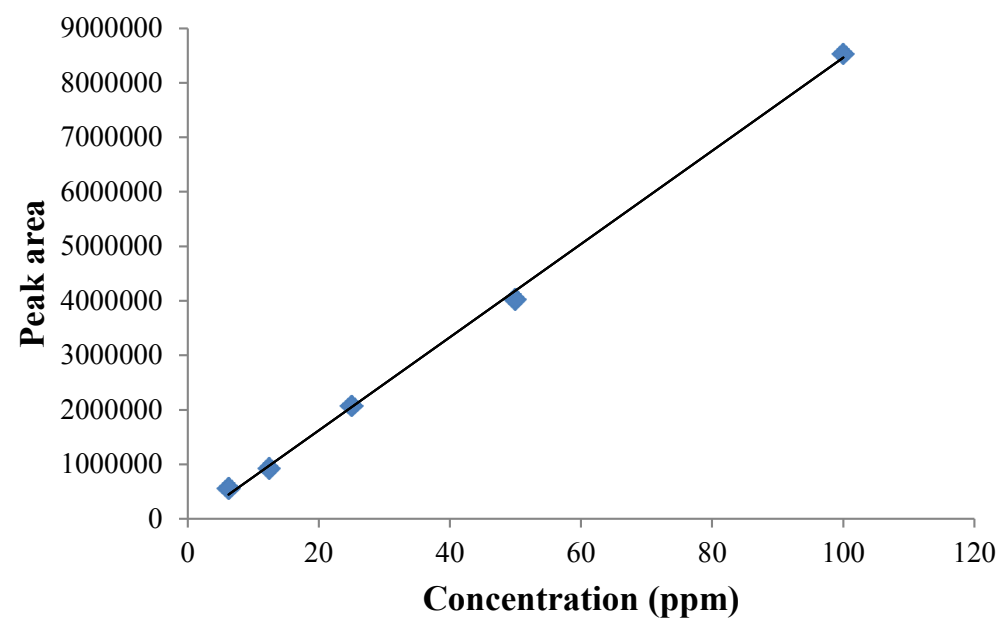

Fig. 3: Calibration curve for TAZQ.

TABLE 2: LINEARITY DATA FOR TAZQ

\begin{tabular}{lcc}
\hline Concentration $(\mathrm{ppm})$ & Mean peak area $\pm \mathrm{SD}(\mathrm{n}=3)$ & \%RSD \\
\hline 6.25 & $562113 \pm 348$ & 0.05 \\
12.5 & $921846 \pm 8401$ & 0.91 \\
25 & $2071154 \pm 34351$ & 1.60 \\
50 & $4025925 \pm 22337$ & 0.55 \\
100 & $8533588 \pm 6306$ & 0.73 \\
\hline
\end{tabular}

SD and \% RSD stand for standard deviation and percent relative standard deviation, respectively

TABLE 3: SUMMARY OF VALIDATIONPARAMETERS

\begin{tabular}{|c|c|c|}
\hline Validation parameter & Observed value & Acceptance criteria ${ }^{[19,21]}$ \\
\hline Linearity & $\begin{array}{c}r^{2}=0.998 \\
\text { Slope }=85510 \\
\text { Intercept }=-90598\end{array}$ & $r^{2} \geq 0.99$ \\
\hline Intraday precision & $\% \mathrm{RSD}=1.2$ & $\% \mathrm{RSD} \leq 2$ \\
\hline Interday precision & $\% \mathrm{RSD}=0.9$ & $\% \mathrm{RSD} \leq 2$ \\
\hline Accuracy & $\%$ recovery $=98 \pm 0.59(n=3)$ & $\%$ recovery $=100 \pm 2 \%$ \\
\hline LOD & 101 ppm & - \\
\hline LOQ & $0.04 \mathrm{ppm}$ & - \\
\hline Robustness & & $\% \mathrm{RSD} \leq 2$ \\
\hline $\begin{array}{l}\text { Flow rate }=1.0 \mathrm{ml} / \mathrm{min} \text {. } \\
\text { Flow rate }=0.8 \mathrm{ml} / \mathrm{min} \text {. }\end{array}$ & $\begin{array}{l}\% \mathrm{RSD}=0.13 \\
\% \mathrm{RSD}=0.20\end{array}$ & \\
\hline Detection $\lambda=259 \mathrm{~nm}$ & $\% \mathrm{RSD}=0.64$ & \\
\hline Detection $\lambda=249 \mathrm{~nm}$ & $\% \mathrm{RSD}=1.67$ & \\
\hline Mobile phase:methanol:water $(82: 18)$ & $\% \mathrm{RSD}=0.40$ & \\
\hline Mobile phase:methanol:water $(78: 22)$ & $\% \mathrm{RSD}=0.65$ & \\
\hline
\end{tabular}

$r^{2}$ and $\lambda$ are correlation coefficient and wavelength, respectively 
of TAZQ and major degradant was found to be 2.27 . Results of forced degradation studies are summed up in Table 5. The peak of TAZQ was distinguishable and quantifiable among the peaks of degradation products and thus the method is stability indicating. The present study is a first report on development and validation of an RP-HPLC method for determination of TAZQ and its successful application as stability indicating assay method. The developed RP-HPLC method was found to be simple, linear, accurate, precise, specific, robust, rapid and suitable. The method effectively separated peaks of TAZQ and degradation products,

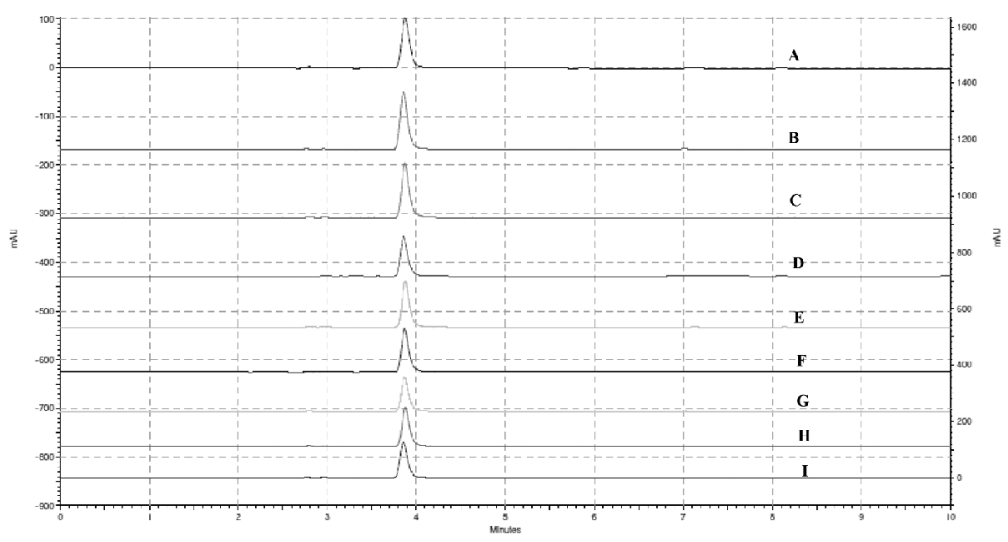

Fig. 4: Chromatograms of degraded samples of TAZQ.

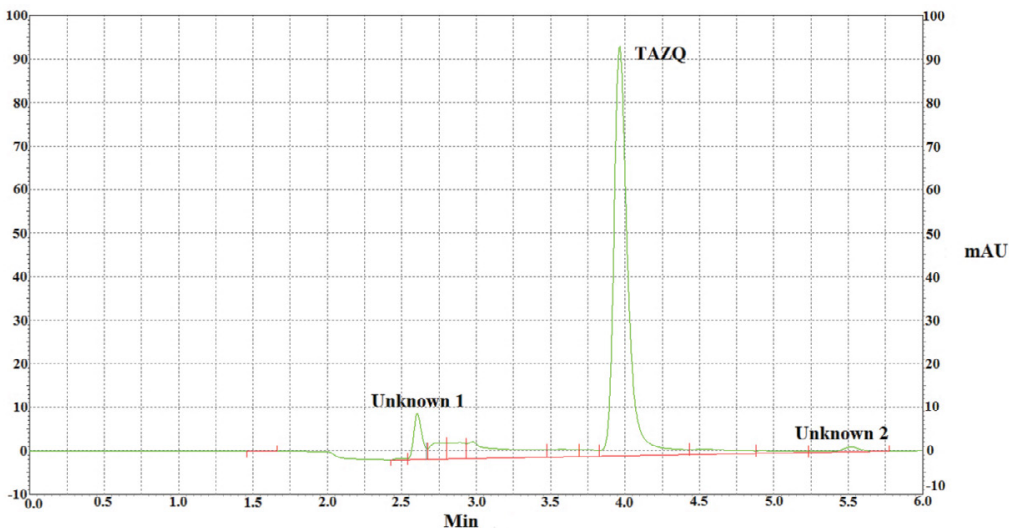

Fig. 5: Chromatogram of base hydrolysed-degraded sample (0.1 N NaOH).

TABLE 4: SUMMARY OF SYSTEM SUITABILITY PARAMETERS

\begin{tabular}{lcc}
\hline Parameter & Observation $(\mathbf{n}=6)$ & Acceptance criteria $^{[19]}$ \\
\hline \%RSD peak area & 1.0 & $\%$ RSD $\leq 1$ \\
\%RSD retention time & 0.22 & $\% R S D \leq 1$ \\
Tailing factor $\left(\mathrm{T}_{\mathrm{f}}\right)$ & $1.283 \pm 0.11$ & $\mathrm{~T}_{\mathrm{f}} \leq 2$ \\
Number of theoretical plates $(\mathrm{N})$ & $11459.5 \pm 1437.5$ & $\mathrm{~N}>2000$ \\
Resolution $(\mathrm{R})$ & $2.27 \pm 0.14$ & $\mathrm{R}>2$ \\
\hline
\end{tabular}

Values for $T_{f}, N$ and $R$ expressed as mean $\pm S D$

\section{TABLE 5: RESULTS OF FORCED DEGRADATION STUDIES OF TAZQ}

Stress condition and duration

Acidic degradation $(0.1 \mathrm{~N} \mathrm{HCl}$, reflux, $30 \mathrm{~min})$

Acidic degradation (1 $\mathrm{N} \mathrm{HCl}, 4 \mathrm{~h})$

Acidic degradation (2 $\mathrm{N} \mathrm{HCl}, 8 \mathrm{~h})$

Acidic degradation (5 $\mathrm{N} \mathrm{HCl}, 1 \mathrm{~d})$

Alkaline degradation $(0.1 \mathrm{~N} \mathrm{NaOH}$, reflux, $30 \mathrm{~min})$

Oxidative degradation $\left(3 \% \mathrm{H}_{2} \mathrm{O}_{2}\right.$, reflux, $\left.30 \mathrm{~min}\right)$

Oxidative degradation $\left(6 \% \mathrm{H}_{2} \mathrm{O}_{2}, 4 \mathrm{~h}\right)$

Photolytic degradation (365 nm UV, $4 \mathrm{~h}$ )

Thermal degradation $\left(80^{\circ}, 4 \mathrm{~h}\right)$
\%Degradation

0

0

0

0

19.85

0

0 
and was capable of measuring their content without interference. Even though no attempt was made to identify the degradation products, this method can be employed for determination of TAZQ and as a stability indicating assay.

\section{Financial support and sponsorship:}

Nil.

\section{REFERENCES}

1. Claeson UP, Malmfors T, Wikman G, Bruhn JG. Adhatoda vasica: a critical review of ethanopharmacological and toxicological data. J Ethnopharmacol 2000;27:1-26.

2. Malhotra S, Kaul SK, Sharma RL, Anand KK, Gupta OP, Dhar KL, et al. Studies on some biologically active azepinoquinazolines: part $\mathrm{I}$ an approach to potent bronchodilatory compounds. Indian J Chem 1988;27B:937-40.

3. Jindal DP, Bhatti RS, Ahlawat S, Bansal R. Synthesis and bronchodilatory activity of some nitrogen bridgehead compounds. Eur J Med Chem 2002;37:419-25.

4. Zabeer A, Bhagat A, Gupta OP, Singh GD, Youssouf MS, Dhar KL, et al. Synthesis and bronchodilator activity of new quinazolin derivative. Eur J Med Chem 2006;41:429-34.

5. Bande M, Nepali K, Goyal R, Thakur V, Suri J, Budhiraja $\mathrm{RD}$, et al. Evaluation of antiasthamatic activity of 7,8,9,10-tetrahydroazeoino[2,1-b]quinazolin-12(6H)-one in combination with ambroxol in guinea pigs. Med Chem Res 2012;21:4158-67.

6. Spulak M, Pourova J, Voprsalove M, Mikusek J, Kunes $\mathrm{J}$, Vacek J, et al. Novel bronchodilatory quinazolines and quinoxalines: synthesis and biological evaluation. Eur J Med Chem 2014;74:65-72.

7. Mahindroo N, Zabeer A, Bhagat A, Bedi KL, Khajuria RK, Kapoor VK, et al. Synthesis and structure-activity relationships of vasicine analog as bronchodilatory agents. Med Chem Res 2005;14:347-68.

8. Johri RK, Zutshi U. Mechanism of action of 6,7,8,9,10,12-hexahydro-azepino-[2,1-]quinazolin-12-one (RLX): a novel bronchodilator. Indian J Physiol Pharmacol 2000;44:75-81.

9. Nepali K, Bande MS, Sapra S, Garg A, Kumar S, Sharma P, et al. Antitussive effects of azepino[2,1-b]quinazolones. Med Chem Res 2012;21:1271-7.

10. Sharma SC, Zutshi U, Dhar KL. Structure elucidation of two more metabolites of 7,8,9,10-tetrahydroazepino[2,1-b]
quinazolin-12(6H)-one, a potent bronchodilator: part II. Indian J Chem 1999;38B:814-7.

11. Sharma SC, Zutshi U, Gupta OP, Dhar KL, Atal CK. Isolation, characterization and partial synthesis of a major metabolite of a potent bronchodilator 7,8,9,10-tetrahydroazepino[2,1B]quinazolin-12(6H)one. Indian J Chem 1996;35B:345-8.

12. Sharma ML, Khajuria A, Kaul A, Chand D. Immunopharmacological properties of azepino[2,1-b] quinazolin-12(6H)-one-7,8,9,10-tetrahydro(RLX). Int J Immunopharmacol 1992;14:979-6.

13. Qazi AK, Hussain A, Aga MA, Ali S, Taneja SC, Sharma PR, et al. Cell specific apoptosis by RLX is mediated by NF- $\mathrm{KB}$ in human colon carcinoma HCT-116 cells. BMC Cell Biol 2014;15:36-44.

14. Qazi AK, Hussain A, Khan S, Aga MA, Behl A, Ali S, et al. Quinazoline based small molecule exerts potent tumor suppressive properties by inhibiting pI3K/akt/FoxO3a signalling in experimental colon cancer. Cancer Lett 2015;359:47-56.

15. http://www.ich.org/fileadmin/Public_Web_Site/ICH Products/Guidelines/Quality/Q1A_R2/Step4/Q1A_R2_ Guideline.pdf.

16. http://www.ich.org/products/guidelines/quality/qualitysingle/article/validation-of-analytical-procedures-text-andmethodology.html.

17. http://www.fda.gov/downloads/drugs//guidances/ucm073384. pdf.

18. http://www.ich.org/fileadmin/Public Web Site/ICH Products/Guidelines/Quality/Q2_R1/Step4/Q2_R1_ Guideline.pd.

19. http://www.fda.gov/downloads/drugs/guidances/ucm134409. pdf.

20. https://hmc.usp.org/sites/default/files/documents/HMC/GCsPdfs/c1225.pdf.

21. http://www.fda.gov/downloads/ScienceResearch/ FieldScience/UCM092147.pdf.

22. Ghulam AS. Validation of high-performance liquid chromatography methods for pharmaceutical analysis. J Chromatogr A 2003;987:57-66.

23. Taverniers I, Loose MD, Backstaele EV. Trends in quality in the analytical laboratory. II. Analytical method validation and quality assurance. Trends Anal Chem 2004;23:535-52.

24. Blessy M, Patel RD, Prajapati PN, Agrawal YK. Development of forced degradation and stability indicating studies of drugs-a review. J Pharm Anal 2014;4:159-65.

25. Ngwa G. Forced degradation as an integral part of HPLC stability-indicating method development. Drug Delivery Technol 2010;10:56-9. 